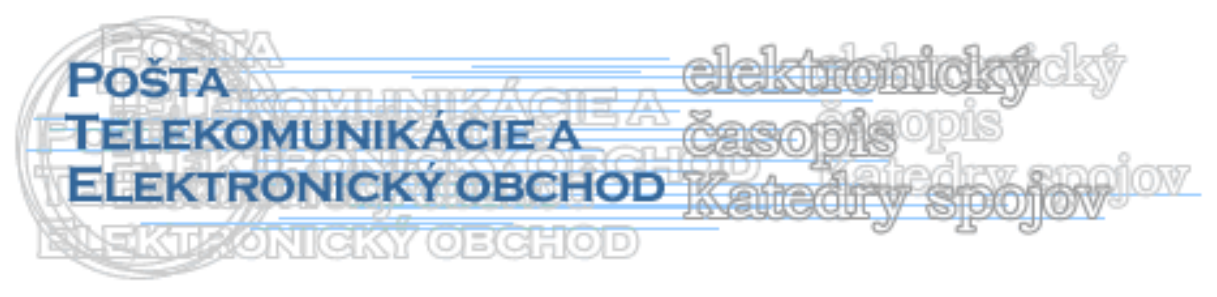

MODERNÝ STRATEGICKÝ PRÍSTUP K INOVÁCIÁM

\author{
Mariana Strenitzerová*
}

\title{
Úvod
}

Ak si chce firma zaistit' dlhodobú konkurenčnú schopnost', nestačí len redukovat' náklady a optimalizovat' procesy. Úspešné inovácie vychádzajú z poznania evolúcie systémov, zo správneho definovania protirečení, zo zvládnutia psychológie, filozofie a ekonomiky inovácií. Inovácie musia integrovat' hlavne procesy obchodu a marketingu, vývoja, výroby, podnikových zdrojov a ich organizácie. Až doteraz sa väčšina podnikov orientovala na stratégiu nízkych nákladov. Éra nízkych nákladov však skončila. Konkurencieschopnost' si musia firmy rozvíjat' kombináciou inovácií a metód pre racionalizáciu organizácie práce a zvyšovania produktivity.

Otázka strategickej orientácie sa stáva kl’účovým faktorom konkurencieschopnosti a úspechu podniku. Fáza definovania strategickej orientácie je v mnohých podnikoch úzkym miestom, avšak podniky, ktoré dokážu pomocou dobrej metodiky systematicky a rýchlo túto fázu zvládnut', si budujú vel'ký konkurenčný náskok.

\section{Inovácia riadenia}

Behom posledného storočia umožnila práve inovácia manažmentu podnikom zásadne zvýšit' ich výkon. Avšak len pár firiem má fungujúci systém priebežného inovovania v oblasti manažmentu. Prakticky každá firma v posledných rokoch systematicky pracovala na tom, aby svoje podnikové procesy zrýchlila a zefektívnila. Avšak len málo podnikov sa snaží uplatnit' ten najdôležitejší typ inovácie - inováciu riadenia.

Inovácie v oblasti riadenia vytvárajú viac konkurenčných výhod ako iné typy inovácií. Inovácie riadenia vytvárajú dlhodobé výhody, pokial' splnia tieto podmienky:

- inovácia musí byt' založená na novátorskom princípe,

- je systémová (zahŕňa viac procesov a metód),

- je súčast'ou prebiehajúceho tvorivého programu, v ktorom sa všetky jednotlivé kroky sčítajú.

Inovácia riadenia sa dá definovat' ako ciel'avedomý odchod od tradičných manažérskych princípov, procesov a praktík takým spôsobom, ktorý mení spôsob riadenia. Tzn. inovácia riadenia mení to, ako manažéri robia to, čo robia.

Obyčajná manažérska práca zahŕňa:

- stanovenie ciel'ov a plánovanie,

- motiváciu,

- koordinačné a kontrolné aktivity,

\footnotetext{
* Ing. Mariana Strenitzerová, PhD., Žilinská Univerzita v Žiline, Fakulta prevádzky a ekonomiky dopravy a spojov, Katedra spojov, Univerzitná 1, 01026 Žilina, Slovenská republika

tel. 00421-041-5133 131, fax 00421-041-5655 615, e-mail: Mariana.Strenitzerova@fpedas.utc.sk
} 
- akumuláciu a alokovanie zdrojov,

- budovanie vzt'ahov,

- identifikáciu a rozvoj talentov,

- prispôsobenie sa vonkajším okolnostiam.

Vo vel'kej firme je možné zmenit' štýl práce manažérov jediným spôsobom: nanovo vytvorit' zásadné riadiace procesy - tzn. prebudovat' ich:

- urobit' $\mathrm{z}$ inovácie ústredný bod v podnikových programoch rozvoja vedenia,

- podstatný diel kapitálových úspor venovat' na projekty, ktoré splnia požiadavky na inovatívnost',

- aby každý plán vývoja produktu obsahoval inovačnú zložku,

- vyškolit' pracovníkov poverených povzbudzovaním inovácií v celom podniku.

Je to dlhodobý proces, ktorý sa ale vyplatí. Inovácia riadiacich princípov a procesov tak môže vytvorit' dlhotrvajúcu výhodu a priniest' výhodné posuny v konkurenčnej pozícií.

\section{Inovačné stratégie}

Inovácie zabezpečujú lepšie výsledky, firma však musí vediet’, aká inovačná stratégia jej môže zaistit' trvalú úspešnost'. Ako zorganizovat' svoje inovácie tak, aby sa stala prispôsobivou na vývoj prostredia, v ktorom pôsobí. Inovácie možno zaradit' do štyroch kategórií podl'a toho, či potrebné zdroje a schopnosti k inováciám existujú vo vnútri firmy alebo mimo nej, či sú už k dispozícii, alebo je nutné ich vytvorit'. Rozlišuje štyri základné prístupy k inováciám - štyri inovačné stratégie:

- Manažment znalostí: Vo vel'kých firmách existuje značné množstvo znalostí a kompetencií. Prispôsobivé, inovatívne firmy sa koncentrujú na efektívne nové využitie a kombináciu existujúcich zdrojov inovácií. Sústred’ujú sa hlavne na tie zdroje, ktoré boli doteraz nevyužité a zostávali bokom pozornosti. Vel'ký dôraz sa kladie na spoločné využívanie znalostí z rôznych odborných oblastí a na ul'ahčenie interného podnikového transferu znalostí.

- Výskum a vývoj: Prispôsobivé, inovatívne firmy sa snažia s vel'kým úsilím získat' nové znalosti. Tie získavajú napr. prostredníctvom výskumných a vývojových stredísk alebo prostredníctvom interných tímov pre vývoj nových myšlienok. Rastie počet l'udí zapojených do získavania nových znalostí, budujú sa interné siete pre získavanie a zdiel'anie znalostí.

- Spolupráca medzi podnikmi: Prispôsobivé, inovatívne firmy kladú dôraz na vyvážený vzt’ah medzi interným výskumom a vývojom a stratégiou spolupráce s inými firmami na vývoji a výskume. Medzifiremná spolupráca umožňuje znížit' riziká spojené $\mathrm{s}$ technologickým vývojom a ponúka prístup k novým trhom alebo k doplňujúcim druhom produktov.

- Podnikatel'ské jednanie: Inovatívne firmy podporujú podnikatel'ské myslenie a jednanie, ako d'alšiu hnaciu silu inovácií. V podnikoch sa stále viac podporuje podnikatel'ský duch. Už nejde len o náklady a obmedzenie rizík, ale taktiež o snahu silnejšie sa sústredit' na potreby a požiadavky zákazníkov a na základe toho formulovat' a využívat' podnikatel'ské šance.

Prispôsobivá, inovatívna firma sa sústred’uje na vyváženú kombináciu všetkých štyroch stratégií. Pravidelne preveruje funkčnost' tejto kombinácie a podl'a potreby túto kombináciu mení, vyvíja. Pokial firma uplatňuje všetky štyri inovačné stratégie súčasne, maximalizuje svoje šance na úspešné prispôsobenie sa meniacemu prostrediu. O investíciách do inovácií by sa nemalo preto rozhodovat' len s ohl'adom na krátkodobý zisk alebo úsporu 
nákladov, ale predovšetkým na prispôsobenie sa dynamickému vývoju prostredia a úspešné prežitie firmy.

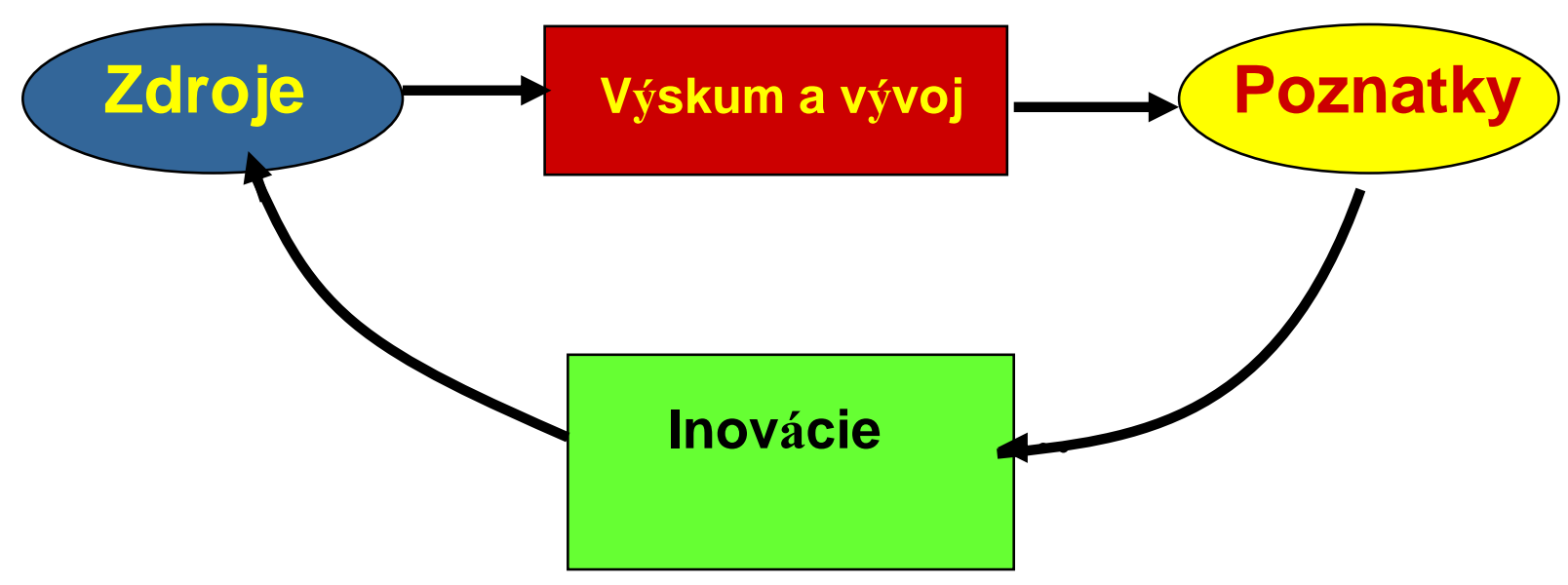

\section{Metodika WOIS}

Metodika WOIS (Wiederspruchorientierte Innovationsstrategie) je v praxi overená metodika, ktorá umožňuje správne strategické nasmerovanie podniku. Zavádza ucelený systém na generovanie a výber inovačných riešení. Je zameraná predovšetkým na riešenie inovačného procesu a popisuje vývoj k vyššiemu systému s pomocou špirály ako kontinuálny a nikdy nekončiaci proces. Špirála ukazuje vývojové vzory z minulosti, slepé uličky, úzke miesta alebo dosiahnuté hranice vo vývojovom procese. Tento prístup umožňuje včasné rozpoznanie bariér vo forme protirečení vývoja.

WOIS integruje do jednotného systému odhal'ovanie stagnácie v oblasti obchodu, techniky, zdrojov a organizácie. Zároveň poskytuje nástroje na systematické hl'adanie strategickej orientácie a súbor prepracovaných postupov na definovanie protirečení a prekonávanie existujúcich bariér.

Základné prvky metodiky WOIS sú:

- definovanie strategického smerovania,

- definovanie protirečení,

- riešenie protirečení s pomocou 46 inovačných princípov hl'adania máp riešení,

- paralelné inovácie obchodu a marketingu, produktov, organizácie a zdrojov.

WOIS posúva svet kompromisov do sveta riešení, v ktorých platí: „Pokial’ si môžete vybrat' dve možnosti, vyberte si obidve“. V minulosti inovácie boli postavené na individuálnych myšlienkových výkonoch, dnes nastáva éra synergie v multiprofesných inovačných tímoch. WOIS je ideálna metodika pre tento spôsob práce.

\section{Hodnotový manažment inovácií}

Hodnotový manažment inovácií, ako ucelená metodológia zameraná na maximalizáciu súčasnej hodnoty pre zákazníka, je rokmi overeným, vel'mi úspešným a efektívnym nástrojom zvyšovania komerčnej úspešnosti a konkurencieschopnosti. Je okrem maximalizácie súčasnej hodnoty pre zákazníka taktiež preukázatel'ne inovačným nástrojom tvorby nových maximálnych hodnôt pre zákazníka, alebo nových produktov uspokojujúcich nové potreby nových zákazníkov na nových trhoch.

Existuje niekol'ko metodických prvkov, princípov a konceptov hodnotového manažmentu inovácií, ktoré sú schopné vytvárat' novú maximálnu hodnotu pre zákazníka.: 
- Funkčný a hodnotový prístup: Hl’adá odpoved’ na otázku ,ako ešte inak, lepšie a efektívnejšie možno zabezpečit' súbor funkcií prinášajúcich úžitok poskytovaný inovovaným objektom a kol'ko nás ten úžitok bude stát?"“, a tak priamo podnecuje k nachádzaniu spôsobov, ktoré inováciami najvyšších rádov zaist’ujú požadované funkcie.

- Identifikácia a odstraňovanie kritických funkcií: Je jadrom funkčnej analýzy a funkčnej syntézy hodnotovej analýzy, ako aplikačnej disciplíny hodnotového manažmentu inovácií. Riešenie rozhodujúcich kritických funkcií má nasledujúcu podobu: Chýbajúce funkcie iniciujú inovačné aktivity k podobe „čo pridat"“, „čo zvýraznit““. Zbytočné funkcie vyvolávajú inovačné reakcie typu „,̌o eliminovat' či ubrat"“, „čo zmiernit"“. Zle plnené funkcie vyvolávajú inovačné reakcie podobné ako u chýbajúcich funkciách.

- Inverzná hodnotová analýza: Svojim uplatnením väčšinou tvorí celkom nové trhy s novými produktmi pre uspokojenie nových potrieb nových zákazníkov. Základnou metodickou otázkou je ,ako ešte ináč, lepšie, efektívnejšie využit' funkcie analyzovaného objektu?" Nájdenie správnej odpovede je väčšinou vo väčšom, dôraznejšom a dominantnom využití doteraz opomínaných funkcií produktu alebo v nájdení iného spotrebitel'ského správania k súčasným či opät' významovo pozmeneným funkciám analyzovaného produktu.

Hodnotový manažment inovácií je dokonale metodicky vybavený na zmeny z funkčne racionálneho na emočné vnímanie a užívanie produktov (a naopak). A to vd’aka detailnému členeniu primárnych funkcií na spotrebné, emotívne, obslužné, obchodne servisné a sociálne ekologické. Je efektívnym metodickým inovačným nástrojom, ktorý účinne pomáha vít'azit' v prostredí nel'útostnej konkurencie cestou maximalizácie súčasných hodnôt pre zákazníka.

\section{Záver}

Inovácie získavajú v rámci podnikových stratégií stále väčší význam. Len firmy, ktoré venujú dostatok zdrojov na inovácie, majú šancu prispôsobovat' sa rýchlo sa meniacemu prostrediu. V súčasnosti začali podniky prikladat' význam inováciám vo funkcii nástroja zásadnej revitalizácie firmy. Investície do inovácií umožňujú následný rast a finančný úspech.

\section{Literatúra}

[1] VLČEK, R.: Hodnotový management inovací. Moderní řízení, 3/2006, ISSN 0026-8720

[2] KOŠTURIAK, J. - DEBNÁR, R.: Principy „lean“ a inovace. Moderní řízení, 7/2006, ISSN 0026-8720

[3] VACULÍK, J. - KRUPPA, M.: Obchodný model novej ekonomiky. Logistika 2/2006, ISSN 1211-0957

\section{Grantová podpora}

Príspevok vznikol na základe riešenia projektu medzinárodnej vedecko-technickej spolupráce Pol/Slov/ŽU/04 „Implementácia metód strategického manažmentu do interného a externého prostredia podniku poskytujúceho služby, ako podporný faktor jeho prosperity“ 